Милица Тарабић

Народна библиотека Ужице

rosic.milica@gmail.com
Стручни рад

UDK 930.85(497.11)"18"

655.4/.5:929 Валожић В.

https://doi.org/10.18485/bibliotekar.2020.62.1.9

\title{
КЊИЖАРСКО-ИЗДАВАЧКИ РАД ВЕЛИМИРА ВАЛОЖИЋА И ЊЕГОВИХ ПОТОМАКА
}

Сажетак: Овај текст посвећен је раду значајног српског издавача и књижара Велимира Валожића, његових синова Душана и Милоша и унука Драгутина. Валожићи су били истински љубитељи књиге и промотори правих културних вредности, оставивши велики траг у књижарској и издавачкој делатности. Велимир је покренуо издавачку делатност и обучио синове који су достојно наставили очев посао. Валожићи су водили књижару у Београду и Нишу, са великим успехом издавали и промовисали књигу и допремали је и до најудаљенијих крајева Србије. Поштено су обављали посао и били цењени међу својим народом, а и шире, послујући са многим европским метрополама. Век књижаре са свим Валожићима, Велимиром, синовима и унуком, трајао је 86 година.

Кључне речи: књижара, књижар, издавач, Велимир Валожић, Душан Валожић, Милош Валожић, Драгутин Валожић.

Први српски књижар и издавач који је тридесетих година 19. века отворио књижару био је Глигорије Возаровић. С обзиром на то да се све дешавало у време Хабзбуршке монархије, када су Срби углавном били образовани и писмени, не чуди што је баш тада у Србији отворена прва књижарска радња која је пословала успешно све до тридесетих година 20. века. „У то време није било друге не само у Београду већ и у целој Кнежевини Србији." Због таквог стања у књижарској делатности Милош Поповић,

Љубомир Дурковић-Јакшић, „Књижара Милоша Поповића и Велимира Валожића”, Гоgишњак Граgа Беоіраga XXVI (1979): 93, http://www.mgb.org.rs/images/godisnjaci/ GodisnjakXXVI/093-121GGBXXVI1979.pdf (преузето 10. 3. 2020). 
уредник Сербских новина, отвара књижару, али је услед недовољно времена да јој се посвети средином 19. века препушта пријатељу Велимиру Валожићу.

Други значајан српски издавач Велимир Валожић рођен је 1814. године у чешком граду Литомишлу, под именом Лауренц Валаух. У родном граду завршио је гимназију, у Прагу је студирао теологију, а након тога медицину у Бечу. Неко време радио је у Аустрији као поштански чиновник. Пошто је био слабог здравља прекинуо је студије и одлучио да промени поднебље. Путовао је по Балкану, заволео Србију и доселио се у Београд 1849. године. Пријали су му срдачност и гостопримство српског народа па је одлучио ту и да остане.

Године 1852. жени се Српкињом Персидом Лазаревић, прелази у православље и добија ново име и презиме: Велимир Валожић. Да би могао да отвори књижару, крајем 1853. године поднео је захтев за добијање српског држављанства, које му је издато 13. септембра наредне године. Са женом Персидом добио је синове Милоша и Душана и ћерку Милеву.

Валожић је имао понуду за посао професора коју је одбио - желео је да настави путем којим је ишао Глигорије Возаровић, власник прве београдске књижаре. Захвалност што је постао књижар дугује пријатељу Милошу Поповићу, уреднику Сербских новина и брату Ђуре Даничића. Милошева књижара на Варош-капији била је место окупљања великог броја интелектуалаца - Јанка Шафарика, Лукијана Мушицког, Ђуре Даничића и других. Ту их Велимир упознаје и проводи доста времена са њима. Најпре је само помагао Милошу у књижари, да би врло брзо почео да ради као пословођа.

Валожић преузима књижару од Поповића у августу 1853. године. Потписан је уговор према коме је дужан да уговорену надокнаду исплати након две године. „Валожић се обавезао 'да ће све силе употребити да књижару подигне и посао њен разпространи', а Поповић да ће му у томе помагати и огласе у Сербским новинама у току једне године бесплатно објављивати, а после тога у пола цене док буде издавао новине.”2 Према уговору књижара је радила под фирмом Милоша Поповића до 8. септембра 1854. године, када Велимир добија одобрење да је пребаци на своје име и преименује у „Књижара Велимира Валожића”.

У време када је Велимир живео и радио, његова књижара била је једина издавачка књижара у Србији. Календар „Млади Шумадинац” био је први издавачки подухват Велимирове књижаре који се издавао од 1858

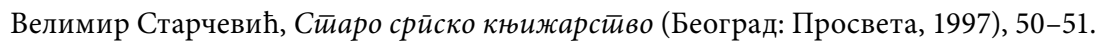




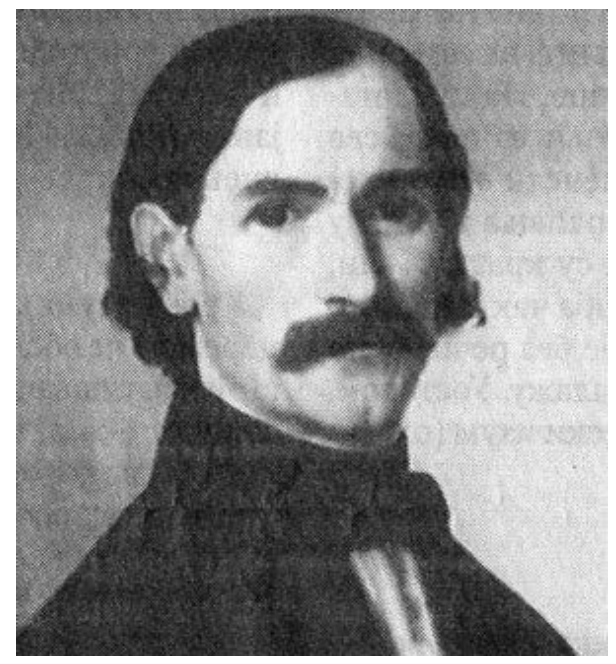

године. „Валожићи су били први издавачи школских уџбеника и дечје литературе у Србији. Пословали су са целом Србијом, са Новим Садом, Сомбором, Суботицом, Будимпештом, Бечом, Прагом, Берлином, Штутгартом, Нирнбергом, Паризом и Миланом, а књигама су снабдевали своју књижару у Нишу, књижару Браће М. Поповић у Новом Саду, књижару Браће Јовановић у Панчеву и књижаре у Кладову, Зајечару, Ужицу, Крагујевцу, Неготину..." ${ }^{3}$ Издавао је литературу за све групе - од школских, научних, занатских до забавних издања, као и преводе страних издања „лепе књижевности”. Издавао је књиге на српском, немачком и француском језику, географске карте и песмарице. Сва издања штампана су само у Државној штампарији у Београду, која се налазила у близини књижаре, а са којом је Велимир потписао посебан уговор. „...Зато је он био једини повлашћени књижар за продају издања Државне штампарије, те су ова издања из његове књижаре даље растурана за распродају преко других ситних књижара како у Београду тако и у унутрашњости. У истом смислу књижара Велимира Валожића била је повлашћено складиште за продају Гласника и свих осталих издања Српског ученог друштва."4

У периоду када је Велимир преузео књижару продавало се између 500 и 600 примерака књиге, а ретко се дешавало поновно издање неког дела. Радио је са многим потешкоћама па је, приликом преноса књижаре на своје име, направио неколико измена у уговору: „1) да књижар може Типографу враћати непродате школске књиге које се више не употребљавају и новим замењивати; 2) да се рабат даје не на 15 насто већ 15 одсто, како би књижара могла да ради без губитака." Иако најпре нису прихваћене, ипак, због своје честитости и ширења посла и ван земље - имао је своје комисионаре

Издавачи и издавашимво у Срба: (1804-1918) (Београд: Art press: Центар за истраживање дигиталне културе, 2016), 12.

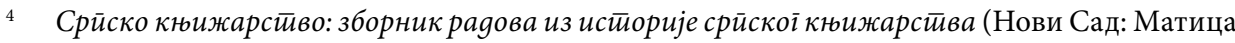
српска: Прометеј, 1997), 384.

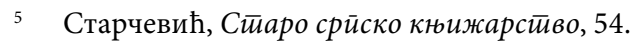


и у Москви, Бечу, Лајпцигу - 1861. године, после скоро 10 година, Министарство просвете му одобрава повластице које омогућавају да отвори 17 књижара у Србији. Велимир је унапредио рад и повећао профит књижаре. Стекао је велики број купаца из Србије а и ван ње, али је значајан део новца губио због додатних трошкова који су прописи захтевали. Почетком 1864. године упутио је молбу Министарству да му одобри рабат од $10 \%$ на све књиге, где је, тек након што га је Државна штампарија подржала рабат одобрен. Од тада се побољшавају услови за приватне књижаре.

Међу првим издавачким подухватима била је и књига Јована Миловановића Новији разіовори коју је Валожић објавио 1864. године, а наредне године објављен је роман Чарлса Дикенса Борба уживотиу и покренута библиотека „Забавна читаоница”. Након тога углавном је издавао романе и кратку прозу. Издавање збирке Црни листиови у којој су се водили записници кривичних догађаја, отпочео је 1887. године, на самом крају живота. Тај посао је након његове смрти наставио син Милош Валожић.

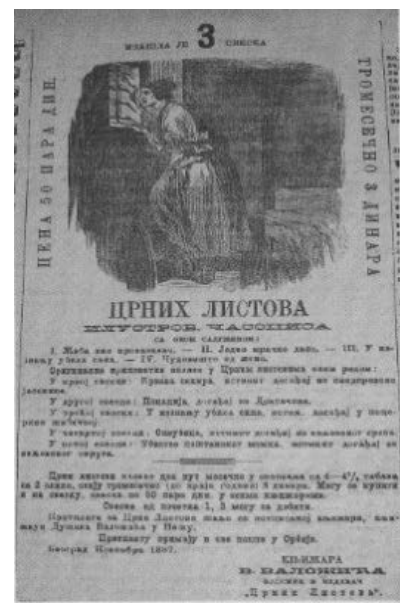

Илустровани часопис Црни листиови

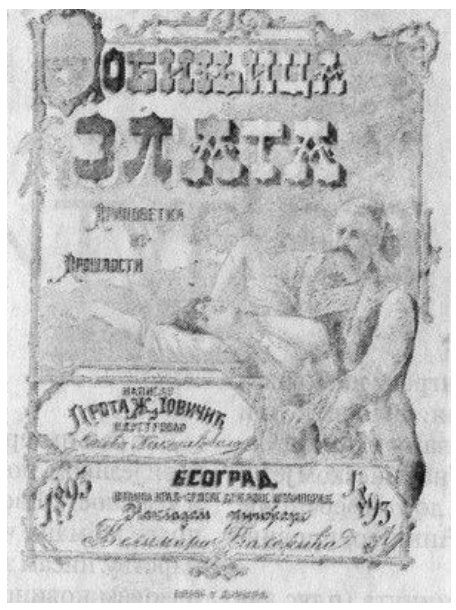

Једно од издања

Велимира Валожића

О издавачкој делатности Књижаре Велимира Валожића, Стојан Новаковић, уважавани филолог, историчар, књижевни критичар (...) писао је: „Књижарница Велимира Валожића унела је у репертоар наше простонародне публике сензационални српски роман, врсту књиге, с којом нисмо ништа добили, а коју су, после нас и други његовали, рачунајући непрестано на велику простонародну публику. Радо признајемо Књижарници В. Валожића да се у свом раду и избору при издавању управљала и 
бољим побудама. Али у њеном раду опет претеже 'што пролази' и оно 'што се тражи'. Избор књижевних дела ређе је тражила од критике и руководних књижевних кругова, а чешће и редовно од купаца простонародне публике..." Чињеница је да је Валожић желео да се приближи читаоцима и задовољи њихове читалачке укусе, али ова Новаковићева критика свакако не умањује све оно што је он урадио за српско књижарство и издаваштво.

Издавачки рад Књижаре Велимира Валожића обухвата 772 наслова7, од чега је:

\begin{tabular}{|l|l|}
\hline Врста грађе & Број јединица \\
\hline Књига & 750 (штампаних 748) \\
\hline Картографске грађе & 10 (5 атласа и 5 географских карата) \\
\hline Часописа, дневних листова & 8 (штампаних) \\
\hline Графика & 4 (разгледнице) \\
\hline
\end{tabular}

Највише су се издавали уџбеници - 361 и кратка проза - 116.

Књижара Велимира Валожића била је „...место окупљања љубитеља књиге, људи од угледа и пера. То је било место укрштања знања, одакле се знање црпло и где се знање уливало". ${ }^{8}$ Њен власник био је образован и достојанствен, добронамеран и предусретљив према свакоме, неко ко је одмах по доласку у Србију стекао углед и поштовање. Много је радио, али није много имао. Био је промотор правих културних вредности и истински љубитељ књиге, без икаквог материјалног интереса.

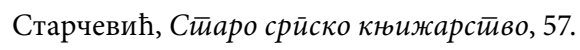

7 Под именом Велимира Валожића издавали су и његов син Милош и унук Драгутин, тако да се 772 наслова односи на издавачки рад све три генерације Валожића. Подаци о библиографским јединицама издатим у Књижари Велимира Валожића и Књижари Душана Валожића могу се пронаћи у Узајамном електронском каталогу COBISS.SR, sr.cobiss.net, као и статистички подаци из осталих табела. Не може се прецизно утврдити колико је ко у току свог рада издао наслова јер се за одређени број публикација не зна година издавања.

8 Ана Стјеља, „Човек који је дао велики допринос популаризацији књиге и развоју књижарства”, Велики људи, 5. 5. 2017, https://velikiljudi.rs/istorija/knizhar-izdavach-prvih-razglednitsau-srbiji/ (преузето 14. 4. 2020). 
Преминуо је 27. децембра 1887. године у Београду. Након његове смрти остало је сећање на љубазног човека који је дао велики допринос популаризацији књиге и развоју књижарства. Стара књижара и кућа Велимира Валожића срушени су после Другог светског рата.

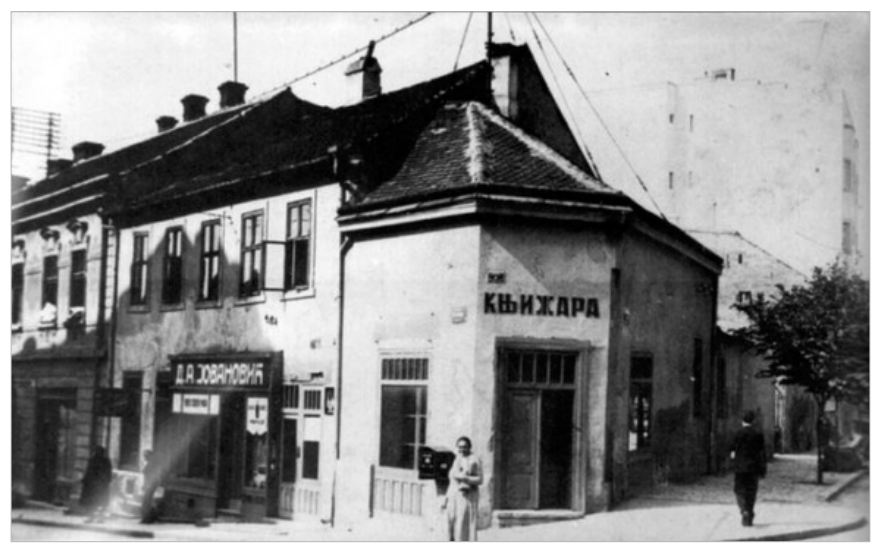

Књижара Велимира Валожића пре рушења

Душан Валожић, млађи син Велимира Валожића, рођен је 1858. године у Београду. Према очевој жељи учио је књижарство у Мађарској и Немачкој. Када се вратио у Србију 1880. године једно време је радио код оца у књижари, а већ следеће године отишао у Ниш где је отворио самосталну књижару са штампаријом под називом „Књижара Душана Валожића”. Међутим, већину својих издања штампао је под фирмом „Књижара Велимира Валожића у Београду и Душана Валожића у Нишу”. Он је најзначајнији нишки књижар и издавач с краја 19. века. ${ }^{9}$

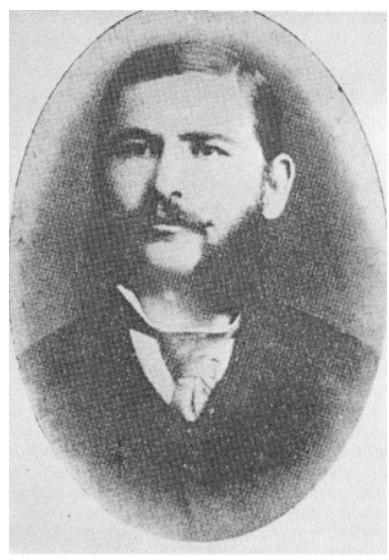

Осим као књижар, био је успешан и у политици. Својом способношћу и борбеношћу успео је да буде изабран за кмета нишке општине 1883. године, а након Тимочке буне постаје посланик Велике народне скупштине. Видети: Старчевић, Старо српско књижарство, 61-62. 
У Душановој књижари издато је 25 наслова, од чега је:

\begin{tabular}{|l|l|}
\hline Врста грађе & Број јединица \\
\hline Књига & 21 (штампана) \\
\hline Картографске грађе & 3 (2 географске карте и 1 атлас) \\
\hline Часопис, дневни лист & 1 (штампани) \\
\hline
\end{tabular}

Душан је око себе окупљао многобројну елиту града Ниша. У својој књижари имао је, поред сопствених, и велики број књига из књижаре Валожића из Београда. Допремао је књиге и до најудаљенијих крајева Србије, чак и у оне под турском влашћу, растурао их и преносио преко граница уз помоћ ђака. Око себе је окупљао омладину којима је преносио знање и саветовао их како да промовишу српску књигу и шире националну свест. За то је добијао признања значајних људи тога доба.

Душан Валожић је умро врло млад, у 31. години, марта 1889. године. Био је то тежак губитак за Ниш. Након његове смрти књижару је преузео Коста Јовановић, родом из Шапца. Бугари су књижару 1915. године спалили, а власника затворили.

У табели ${ }^{10}$ представљена су дела која су издата у Књижари Велимира Валожића у Београду и истовремено у Књижари Душана Валожића у Нишу:

\begin{tabular}{|l|l|l|l|l|}
\hline P.Б. & \multicolumn{1}{|c|}{ Аутор } & Наслов & Врста грађе & $\begin{array}{l}\text { Год. } \\
\text { изд. }\end{array}$ \\
\hline 1. & Бабавник: календар за просту & $\begin{array}{l}\text { серијске } \\
\text { публикације }\end{array}$ & $\begin{array}{l}18 ? ?- \\
1 ? ? ?\end{array}$ \\
\hline 2. & годину & $18 ? ?$ \\
\hline 3. & Благоје Т. Недић & $\begin{array}{l}\text { Познавање и неговање човечијег } \\
\text { тела: за ІІІ разред основне школе } \\
\text { тела: за IV разред основне школе }\end{array}$ & уџбеник & $18 ? ?$ \\
\hline 4. & Аdolf Streckfuss & $\begin{array}{l}\text { Ујак и сестрић: криминална } \\
\text { новела }\end{array}$ & кратка проза & $18 ? ?$ \\
\hline 5. & Јован Бешлић & $\begin{array}{l}\text { Карта Краљевине Србије: за сва- } \\
\text { кога а нарочито за ученике основ- } \\
\text { них и средњих школа }\end{array}$ & $\begin{array}{l}\text { картографска } \\
\text { грађа }\end{array}$ & $1884 ?$ \\
\hline
\end{tabular}

10 COBISS.SR, http://sr.cobiss.net (преузето 9. 6. 2020). 


\begin{tabular}{|l|l|l|l|l|}
\hline 6. & Jован Бешлић & $\begin{array}{l}\text { Таблице за прорачунавање непо- } \\
\text { средног пореза интереса, казни, } \\
\text { одбитка одбитка и приреза као } \\
\text { и месечне отплате непосредног } \\
\text { пореза }\end{array}$ & књига & 1885 \\
\hline 7. & Јован Бешлић & $\begin{array}{l}\text { Таблице за прорачунавање непо- } \\
\text { средног пореза допуњујућгг поре- } \\
\text { за на обрт приреза, интереса, каз- } \\
\text { ни, одбитка, војнице и крчмарине }\end{array}$ & књига & 1887 \\
\hline 8. & $\begin{array}{l}\text { Јоксим Ст. } \\
\text { Марковић }\end{array}$ & $\begin{array}{l}\text { Српска историја за нижу основну } \\
\text { школу }\end{array}$ & уџбеник & 1888 \\
\hline 10. & Адолф Штрекфус & $\begin{array}{l}\text { Ујак и сестрић: криминална } \\
\text { новела }\end{array}$ & 1888 \\
\hline 11. & Субертус Теме & $\begin{array}{l}\text { Верујте у бога: криминална } \\
\text { новела }\end{array}$ & $\begin{array}{l}\text { кратка проза } \\
\text { Кратка проза }\end{array}$ & 1888 \\
\hline 12. & Јован Бешлић & $\begin{array}{l}\text { Катастер (тапија) и баштинска } \\
\text { књига за потребу Краљевине } \\
\text { Србије }\end{array}$ & $\begin{array}{l}\text { картографска } \\
\text { грађа }\end{array}$ & $1890 ?$ \\
\hline 13. & Јован Бешлић & $\begin{array}{l}\text { Карта Краљевине Србије: за уче- } \\
\text { нике основних и средњих школа. 1 }\end{array}$ & $\begin{array}{l}\text { картографска } \\
\text { грађа }\end{array}$ & 1890 \\
\hline
\end{tabular}

Милош је био старији син Велимира Валожића који је наставио очев издавачки рад. Рођен је у Београду 1853. године. Најпре је оцу само помагао и уз њега научио много о књигама и књижарском послу, а касније га је наследио. Од оца је научио најважнију ствар - да се књига у што већем броју примерака прода, као и да стигне у најудаљенија и најприступачнија места. ${ }^{11}$

Милош Валожић је, за разлику од оца, поред Државне штампарије штампао и код приватних штампара. Није хтео да мења назив фирме у знак поштовања према оцу, познатом књижару

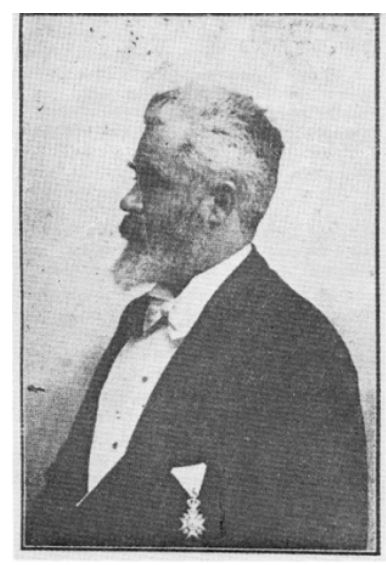

11 Књиге из Валожићеве књижаре доспеле су до Турске и Аустрије уз помоћ момка Петра који је радио за њега и са корпама пуним књига обилазио целу Србију и књиге учинио доступним свима. Видети: Старчевић, Сйаро срйско књижарсӣво, 58. 
и штампару, али и зато што је фирма већ била чувена и позната по очевом имену. Наставио је и са праксом штампања разгледница. У издавачком послу помагао му је Милован Глишић.

У периоду када је Милош водио књижару највише су се издавали уџбеници и кратка проза. У првој години његовог рада издате су две књиге кратке прозе Беоіраg у йами Тасе Ј. Миленковића и збирка кратке прозе Кесароши истог аутора. Исте године издате су и криминалне приповетке „Црни дани”, „Ко је убица”, „Ујак и сестрић” и „Верујте у бога” страних аутора. Наредних година издавао је збирке кратке прозе Јанка Веселиновића, романе, поезију, велики број уџбеника... Последњих пет година 20. века биле су му најуспешније - издао је преко 100 наслова. Углавном су то били уџбеници за основну школу и збирке кратке прозе.

Милош Валожић је био образован, поштен као његов отац. Окупљао је око себе највиђеније интелектуалце тог времена, као и књижевнике чије је радове издавао - Стевана Сремца, Јанка Веселиновића, Радоја Домановића и друге. Често је учествовао у добротворним акцијама у којима су се књиге поклањале сиромашној деци. Године 1895. основао је за ученике нижих разреда у I Београдској гимназији ђачку библиотеку „Задужбина Милоша Валожића”. ${ }^{2}$ Био је привржен својој земљи и свом народу. „Био је то велики српски родољуб. За време окупације Босне и Херцеговине, у знак протеста, Књижару је држао затворену седам дана."13

Милош Валожић је водио књижару до 15. августа 1909. године када је несрећним случајем изгубио живот тако што је пао под воз. Његов посао најпре је наследио син Михаило, међутим, брзо је напустио књижару, па је Милошев рад наставио његов други син Драгутин, уједно и последњи власник књижаре.

Драгутин Валожић је углавном издавао уџбенике за основне школе и картографску грађу - првих година издавао је наслове Михаила Сретеновића: Мала ірамайика, Поуке за домаћице, Истиорија срйскоїа нароgа. Објавио је Земльоиис Србије и срйских земаль Михаила Јовића, Познавағе üрироgе Димитрија Путниковића, објављивао је читанке, рачунске задатке, атласе... Памте га по идеји да 1921. године, заједно са још 11 књижара, оснује Књижарско удружење. ${ }^{14}$

12 Ову библиотеку основао је за успомену на рано преминулог сина, ученика те гимназије.

13 Дурковић-Јакшић, „Књижара Милоша Поповића и Велимира Валожића”, 118.

14 Може се наћи и податак да је пре почетка Другог светског рата Драгутин јефтино продао вредну преписку деде Велимира са песником Ђуром Јакшићем, очито због финансијских проблема. Видети: Ана Стјеља, „Човек који је дао велики допринос популаризацији књиге 
Водио је посао до 1939. године, када је издат налог да се књижара сруши. Након тога, на њеном месту подигнута је вишеспратница. То је био крај Књижаре Велимира Валожића, књижаре у којој су три генерације радиле на развоју издаваштва, продаје и дистрибуције књига у Србији.

Након 75 година од нестанка књижаре, београдском књижару и издавачу Велимиру Валожићу дато је признање за његов рад и целокупно залагање у области књижарства и издаваштва - 4. септембра 2014. године откривена му је спомен-плоча у Улици Косанчићев венац, на месту где се некада налазила његова књижара. Спомен-плочу је открио најстарији члан породице Предраг Валожић, након чега је у Библиотеци града Београда отворена изложба „Велимир Валожић - београдски књижар и издавач”.

Валожићи су, на челу са Велимиром, заједно дали велики допринос популаризацији књиге и развоју књижарства. Заједно са својим синовима Душаном и Милошем и унуком Драгутином, Велимир је оставио велики траг у културној историји Београда и Србије.

и развоју књижарства”, Велики људи, 5. 5. 2017, https://velikiljudi.rs/istorija/knizhar-izdavachprvih-razglednitsa-u-srbiji/ (преузето 14. 4. 2020). 


\title{
Literatura
}

1. Durković-Jakšić, Ljubomir. „Knjižara Miloša Popovića i Velimira Valožića”. Godišnjak Grada Beograda XXVI (1979), http://www.mgb.org.rs/images/godisnjaci/ GodisnjakXXVI/093-121GGBXXVI1979.pdf (preuzeto 10. 3. 2020). (na ćirilici)

2. Izdavači i izdavaštvo u Srba: (1804-1918). Beograd: Art press: Centar za istraživanje digitalne kulture, 2016. (na ćirilici)

3. Srpsko knjižarstvo: zbornik radova iz istorije srpskog knjižarstva. Novi Sad: Matica srpska: Prometej, 1997. (na ćirilici)

4. Starčević, Velimir. Staro srpsko knjižarstvo. Beograd: Prosveta, 1997. (na ćirilici)

\section{Milica Tarabić}

Public Library of Užice

rosic.milica@gmail.com

\section{VELIMIR VALOŽIĆ AND HIS DESCENDANTS AS THE BOOKSELLERS AND PUBLISHERS}

\begin{abstract}
The paper deals with the work of an important Serbian publisher and bookseller Velimir Valožić, his sons Miloš and Dušan, and grandson Dragutin. The members of the Valožić family were true book lovers and promoters of real cultural values, leaving a significant mark on book publishing activities. Velimir started the publishing business and trained his sons, who continued their father's work with dignity. The Valožićs ran a bookstore in Belgrade and Niš, published and promoted books with great success, and delivered them to the most remote parts of Serbia. They did their job honorably and were respected among their fellow countrymen, and beyond, cooperating with many European metropolises. The Valožićs, Velimir, his sons and grandson, ran the bookstore for 86 years.
\end{abstract}

Keywords: bookstore, bookseller, publisher, Velimir Valožić, Dušan Valožić, Miloš Valožić, Dragutin Valožić.

Примљено: 15. априла 2020.

Исправке: 5. јуна 2020.

Прихваћено: 23. јуна 2020. 